JeMAS 15 (3) (2020) 338-343
Jitp://journal.unnes.ac.id/nju/index.php/kemas

\title{
Factors Associated with Depression among Prisoners in Women's Class II-A Prison Jakarta
}

Zhara Juliane, Putri Bungsu Machmud ${ }^{\bowtie}$

Departement of Epidemiology, Faculty of Public Health, University of Indonesia

\section{Article Info}

Article History:

Submitted July 2019

Accepted November 2019

Published March 2020

Keywords:

Depression,

Prisoners, Women's

Class II-A Prison Jakarta

DOI

https://doi.org/10.15294/

kemas.v15i3.19850

\begin{abstract}
Depression is a common mental disorder, characterized by persistent sadness and a loss of interest in activities that you normally enjoy, accompanied by an inability to carry out daily activities, for at least two weeks. Female prisoners represent groups at risk of depression where depression in prisoners is more vulnerable to female prisoners than men. This study aims to determine the factors associated with depression among prisoners in Women's Class II-A Prison Jakarta. The study design used was cross-sectional with multivariate analysis, multiple logistic regression. The number of research samples is 200 prisoners taken using random sampling techniques. The results showed that the prevalence of depression among prisoners in Women's Class II-A Prison Jakarta is $56,5 \%$. Based on the results of the multivariate analysis, it can be seen that factors related significantly to depression are age ( $\mathrm{p}$-value $=0.012 ; \mathrm{POR}=2.144 ; 95 \% \mathrm{CI}=1.185-3.879$ ) and recidivism status ( $\mathrm{p}$-value $=0.043$; $\mathrm{POR}=3.926 ; 95 \% \mathrm{CI}=1,047-14,729$ ) which the most influential factor on the incidence of depression is recidivism status. Government attention needs to be given to the mental health of prisoners by conducting various mental health programs and services such as regular screening and rehabilitation programs. .
\end{abstract}

\section{Introduction}

The conditions at Prison are certainly much different from the conditions in the community. The difference in conditions is not easy to be lived and accepted by prisoners (Gulo, 2015). Under these conditions, prisoners are required to be able to adjust to life in prisons (Gulo, 2015). Situations and conditions that are full of demands and pressures due to sudden environmental changes often result in prisoners becoming vulnerable and potentially experiencing various kinds of mental health disorders, including depression (Gulo, 2015).

Depression is a mental disorder, characterized by persistent sadness and a loss of interest in activities that you usually enjoy, accompanied by an inability to carry out daily activities, for at least two weeks (World Health Organization, 2018). Depression is a common mental disorder worldwide, with more than 300 million people affected (World Health Organization, 2018). Moreover, depression is also the leading cause of disability worldwide and is a significant contributor to the overall global burden of disease (World Health Organization, 2018). Also, The WHO also predicts that in 2020, depression will occupy the second largest cause of health problems after cardiovascular disease (Thabrany \& Pujianto in (Nora, 2011). In Indonesia, the prevalence of depression in people aged $\geq 15$ years has reached 6.1\% (Riskesdas, 2018).

Research that has been carried out in various countries reveals that the prevalence of depression in prison populations is higher than the general population (T.K Beyen, 2017). Also, the World Health Organization (WHO) estimates that out of 9 million prisoners 
worldwide, at least 1 million (11\%) suffer from significant mental disorders, where the most common mental health problems are depression (World Health Organization, 2008). However, most studies report the incidence of depression in prisoners as more vulnerable to female prisoners than men (Gunenthira Rao, 2018). This can occur because several factors, including that women, are more sensitive to their feelings, so they tend to face feelings based on beliefs rather than rational considerations (Utami, 2011).

The above situations show that prisoners, especially women, are at risk for depression (Gunenthira Rao, 2018). Based on a systematic review involving 24 western countries, $14.1 \%$ of female prisoners experience depression (Seewald, 2012). However, until now, mental health problems are still a problem that seems to be neglected in prisons. In fact, if the condition is not detected and dealt with, it can lead to increasingly severe mental health disorders, disability, and the worst that can lead to suicide in prisoners (Gunenthira Rao, 2018). The purpose of this study was to determine the factors associated with the level of depression in prisoners at the Women's Class II-A Prison Jakarta.

\section{Method}

This research is an observational type with a quantitative approach. The research design used was cross-sectional, where the independent variables and dependent variables were obtained at the same time. The population in this study were all Prisoners in Women's Class II-A Prison Jakarta. The samples used in this study were 200 prisoners who met the inclusion criteria and obtained using random sampling techniques.

The study was conducted from January to April 2019. The dependent variable in this study was the level of depression in prisoners in Women's Class II-A Prison Jakarta with independent variables such as age, education level, marital status, current disease status, social support status, participation in coaching status, types of violations, length of sentence, duration of prison stay, and recidivism status for prisoners in Women's Class II-A Prison Jakarta.

This study uses two data sources, which are primary data sources and secondary data sources. The primary data sources are obtained using instruments in the form of a questionnaire consisting of three parts. The first part is the sociodemographic questionnaire, the second part is a questionnaire to assess the depression level variable using the Indonesian version of the Beck Depression Inventory-II (BDI-II) questionnaire and the third part is a questionnaire to assess social support variables using a questionnaire adapted from Sulastri (2013), which the questionnaire was developed based on the Interpersonal Support Evaluation List (ISEL) of Cohen \& Hoberman (1983).

Whereas for variables such as age, education level, type of violation, length of sentence, duration of a prison stay, and recidivism status are sourced from secondary data obtained from the database belonging to the registration division of Women's Class II-A Prison Jakarta. In this study, data analysis was carried out in univariate, bivariate using chisquare analysis and multivariate analysis using logistic regression analysis.

\section{Result and Discussion}

The distribution of respondents based on the characteristics that can be found in table 1 shows that the prevalence of depression in prisoners at the Women's Class II-A Prison Jakarta is $56.5 \%$ so that it can be said that more than half of prisoners are depressed. In addition, table 1 also shows that the majority of prisoners are at the age of $<40$ years (62\%), have high education level (44.5\%), have married marital status (45\%), have no current disease status (74\%), has a low social support status $(50.5 \%)$, is active in coaching $(64 \%)$, has a type of narcotics violation (78\%), and is a nonrecidivist prisoner (92.5\%).

Based on the bivariate analysis that can be found in table 2 , the variables significantly associated with the level of depression were age ( $\mathrm{p}$-value $=0.029)$. While the variables such as education level, marital status, current disease status, social support status, participation in coaching status, types of violations, length of sentence, duration of a prison stay, and recidivism status did not show a significant relationship with the level of depression ( $p$ value $>0.05$ ).

Variables that entered into multivariate 
Table 1. Univariate Distribution of Respondent's Characteristics

\begin{tabular}{|c|c|c|}
\hline Variables & $\mathrm{n}$ & $\%$ \\
\hline \multicolumn{3}{|l|}{ Level of Depression } \\
\hline Normal & 87 & 43,5 \\
\hline Depression & 113 & 56,5 \\
\hline \multicolumn{3}{|l|}{ Age } \\
\hline$>=40$ & 76 & 38 \\
\hline$<40$ & 124 & 62 \\
\hline \multicolumn{3}{|l|}{ Education Level } \\
\hline High & 111 & 55,5 \\
\hline Low & 89 & 44,5 \\
\hline \multicolumn{3}{|l|}{ Marital Status } \\
\hline Married & 90 & 45 \\
\hline Single & 34 & 17 \\
\hline Divorce & 76 & 38 \\
\hline \multicolumn{3}{|c|}{ Current Disease Status } \\
\hline No & 148 & 74 \\
\hline Yes & 52 & 26 \\
\hline \multicolumn{3}{|l|}{ Social Support Status } \\
\hline High & 99 & 49,5 \\
\hline Low & 101 & 50,5 \\
\hline \multicolumn{3}{|c|}{ Participation in Coaching Status } \\
\hline Active & 128 & 64 \\
\hline Less Active & 72 & 36 \\
\hline \multicolumn{3}{|l|}{ Types of Violations } \\
\hline Criminal & 44 & 22 \\
\hline Narcotics & 156 & 78 \\
\hline \multicolumn{3}{|l|}{ Length of Sentence } \\
\hline$>5$ years & 78 & 39 \\
\hline$<=5$ years & 122 & 61 \\
\hline \multicolumn{3}{|c|}{ Duration of Prison Stay } \\
\hline$>=2$ years & 154 & 77 \\
\hline$<2$ years & 46 & 23 \\
\hline $\begin{array}{l}\text { Recidivism Status } \\
\text { Non Recidivist }\end{array}$ & 185 & 92,5 \\
\hline Recidivist & 15 & 7,5 \\
\hline
\end{tabular}

Source: Primary Data, 2019

modeling after bivariate selection were age and recidivism status with $\mathrm{p}$-value $\leq 0.25$. Based on the latest multivariate modeling that can be found in Table 3, It shows that from the results of multivariate analysis two variables are statistically significant with the level of prisoner depression, which are age variable ( $\mathrm{p}$-value $=$ 0.012 ) and recidivism status variable ( $\mathrm{p}$-value $=0.043$ ). Therefore, it can be concluded that the independent variable that can predict the incidence of depression in prisoners at Women's Class II A Prison Jakarta is age and recidivism status and it showed that the most dominant variable is the recidivism status variable. The results of the analysis showed that adjusted odds ratio (AOR) of recidivism status variables was 3,926 (95\% CI: 1,047-14,729), meaning recidivist prisoners (having previously held detention for repetition of crime) were 3,926 times or almost four times as likely to be depressed than non-recidivist inmates (inmates who have been detained for the first time).

The prevalence of depression in prisoners at Women's Class II-A Prison Jakarta is $56.5 \%$. The Riskesdas 2018 data shows that the prevalence of depression in people aged $\geq 15$ years in Indonesia reaches $6.1 \%$. So when compared with the results of the 2018 Riskesdas, the prevalence of depression in prisoners at Women's Class II-A Prison Jakarta is very different and falls into the reasonably high category. However, this can occur because this research is not carried out in healthy populations but in populations at risk namely, prisoners whose prevalence is higher than the healthy population can occur due to differences 
Table 2. Analysis on Independent Variable with Level of Depression

\begin{tabular}{|c|c|c|c|c|c|c|c|c|}
\hline \multirow{3}{*}{ Variables } & \multicolumn{4}{|c|}{ Level of Depression } & \multirow{2}{*}{\multicolumn{2}{|c|}{ Total }} & \multirow{3}{*}{ P-value } & \multirow{3}{*}{ POR $(95 \% \mathrm{CI})$} \\
\hline & \multicolumn{2}{|c|}{ Depression } & \multicolumn{2}{|c|}{ Normal } & & & & \\
\hline & $\mathrm{n}$ & $\%$ & $\mathrm{n}$ & $\%$ & $\mathrm{~N}$ & $\%$ & & \\
\hline \multicolumn{9}{|l|}{ Age } \\
\hline$<40$ & 78 & 62,9 & 46 & 37,1 & 124 & 100 & \multirow{2}{*}{$0,029^{*}$} & \multirow{2}{*}{$\begin{array}{l}1,986 \\
(1,112-3,547)\end{array}$} \\
\hline$>=40$ & 35 & 46,1 & 41 & 53,9 & 76 & 100 & & \\
\hline \multicolumn{9}{|l|}{ Education Level } \\
\hline Low & 54 & 60,7 & 35 & 39,3 & 89 & 100 & \multirow{3}{*}{0,356} & \multirow{3}{*}{$\begin{array}{l}1,360 \\
(0,772-2,394)\end{array}$} \\
\hline High & 59 & 53,2 & 52 & 46,8 & 111 & 100 & & \\
\hline \multicolumn{7}{|l|}{ Marital Status } & & \\
\hline Divorce & 43 & 56,6 & 33 & 43,4 & 76 & 100 & \multirow{3}{*}{0,948} & \multirow{3}{*}{$\begin{array}{l}1,042 \\
(0,563-1,929) \\
1,143 \\
(0,514-2,542)\end{array}$} \\
\hline Single & 20 & 58,8 & 14 & 41,2 & 34 & 100 & & \\
\hline \multirow{2}{*}{\multicolumn{8}{|c|}{ Current Disease Status }} & \\
\hline Yes & 31 & 59,6 & 21 & 40,4 & 52 & 100 & \multirow{2}{*}{0,716} & \\
\hline No & 82 & 55,4 & 66 & 44,6 & 148 & 100 & & \multirow{2}{*}{$\begin{array}{l}1,188 \\
(0,625-2,257)\end{array}$} \\
\hline \multicolumn{8}{|l|}{ Social Support Status } & \\
\hline Low Social Support & 61 & 60,4 & 40 & 39,6 & 101 & 100 & \multirow{2}{*}{0,327} & \multirow{2}{*}{$\begin{array}{l}1,378 \\
(0,787-2,415)\end{array}$} \\
\hline $\begin{array}{l}\text { High Social Support } \\
\text { Participation in Coaching }\end{array}$ & 52 & 52,5 & 47 & 47,5 & 99 & 100 & & \\
\hline \multicolumn{9}{|l|}{ Status } \\
\hline Active & 72 & 56,3 & 56 & 43,8 & 128 & 100 & 1,000 & $\begin{array}{l}1,029 \\
(0,574-1,842)\end{array}$ \\
\hline \multicolumn{9}{|l|}{ Types of Violations } \\
\hline Narcotics & $\begin{array}{l}90 \\
23\end{array}$ & $\begin{array}{l}5 /, 7 \\
52,3\end{array}$ & $\begin{array}{l}66 \\
21\end{array}$ & $\begin{array}{l}42,3 \\
47,7\end{array}$ & $\begin{array}{l}156 \\
44\end{array}$ & $\begin{array}{l}100 \\
100\end{array}$ & \multirow[t]{2}{*}{0,640} & \multirow{2}{*}{$\begin{array}{l}1,245 \\
(0,636-2,437)\end{array}$} \\
\hline \multicolumn{7}{|l|}{ Length of Sentence } & & \\
\hline$>5$ years & 42 & 53,8 & 36 & 46,2 & 78 & 100 & \multirow[t]{2}{*}{0,646} & $\begin{array}{l}1,193 \\
(0,673-2,115)\end{array}$ \\
\hline $\begin{array}{l}£ 5 \text { years } \\
\text { Duration of Prison Stay }\end{array}$ & 71 & 58,2 & 51 & 41,8 & 122 & 100 & & \\
\hline${ }^{3} 2$ years & 86 & 55,8 & 68 & 44,2 & 154 & 100 & 0,863 & $\begin{array}{l}1,124 \\
(0.576-2.190)\end{array}$ \\
\hline$<2$ years & 27 & 58,7 & 19 & 41,3 & 46 & 100 & & \\
\hline Recidivism Status & & & & & & & & \\
\hline Recidivist & 12 & 80 & 3 & 20 & 15 & 100 & & 3,327 \\
\hline Non Recidivist & 101 & 54,6 & 84 & 45,4 & 185 & 100 & 0,101 & $(0,909-12,180)$ \\
\hline
\end{tabular}

*signifikan $(p$ value $<0,05)$

Source: Primary Data, 2019

Table 3. Final Model Of Multivariate Analysis

\begin{tabular}{llll}
\hline Variables & OR Adjusted & $95 \%$ CI & P-value \\
\hline Age & 2,144 & $1,185-3,879$ & 0,012 \\
Recidivism Status & 3,926 & $1,047-14,729$ & 0,043 \\
\hline Source: Primary Data, 2019 & &
\end{tabular}

in conditions and situations between prisoners with healthy communities such as stressful environment, prisoner limitations to carry out activities, and isolation from family and closest people.

In multivariate analysis, it was found that there was a statistically significant relationship ( $\mathrm{p}$-value $=0.012)$ between age and level of depression in prisoners at the Women's Class II-A Prison Jakarta. While the results of the risk analysis obtained an adjusted OR value of 2.144 (95\% CI: 1.185 - 3.879), meaning that prisoners aged $<40$ years have a risk of 2,144 times to become depressed when compared to prisoners aged $\geq 40$ years or in other words prisoners with $<40$ years of age are twice the risk of becoming depressed compared to prisoners aged $\geq 40$ years.

The results of the study are in line with research (Datta, et al., 2015) and (Bhuyan \& Das, 
2012) which shows that there is a significant relationship between age with depression. Both studies have shown that prisoners belonging to the young-adult group have a higher risk of suffering from depression compared to other age groups.

Various studies and surveys showed that depression is more common in these age groups because, in those age groups, they tend to think about how they should look, how they should behave, what they should have, and other needs by comparing them with others (Action Mental Health, 2019). Also, inmates in the young adult group usually have a history of alcohol and other substances before detention, which might cause them to experience depression (Zakir Abdu, 2018).

The results of multivariate analysis in this study showed that there was a statistically significant relationship $(\mathrm{p}$-value $=0.043)$ between recidivism status and the level of depression in prisoners at the Women's Class II-A Prison Jakarta. While the results of risk analysis obtained OR adjusted value of 3,926 (95\% CI: 1,031 - 14,527), meaning that recidivist prisoners have a risk of 3,926 times to become depressed compared to non-recidivist prisoners in other words recidivist prisoners (having previously held detention due to repetition criminal) has a four-fold risk of becoming depressed compared to non-recidivist inmates (inmates who have been detained for the first time).

The results of this study are in line with the research of Abdu, et al. (2018) which showed that there is a statistically significant relationship ( $\mathrm{p}$-value $=<0.001$ ) between recidivism status and the level of depression of prisoners. The results of the risk analysis found an adjusted OR of 7.45 (95\% CI: 2,758 - 20,152), meaning that prisoners who were recidivist or had previously held detention had a risk of 7.45 times being depressed compared to non-recidivist inmates or the first time they were detained.

The results in the study showed that there was a statistically significant relationship between the status of recidivism and the level of depression in prisoners at the Women's Class II-A Prison Jakarta. This can occur because of a variety of possibilities, including recidivist prisoners who tend to get repeated exposure to the prison environment, which is full of stressors (Shrestha et al., 2017). Also, this can also occur because recidivist prisoners must endure social relations disorders and social isolation again after the previous release process which can cause worse symptoms of depression (Shrestha et al., 2017).

However, there are some limitations to this study. Since the design of the study used is a cross-sectional design so that it did not allow establishing a temporal relationship between depression and associated factors. Also, there is no difference in the proportion between several independent variables and the dependent variable which can occur due to the lack of the number of respondents involved so that further research is recommended to add respondents so that the resulting data is more representative and comprehensive.

\section{Conclusion}

The prevalence of depression in prisoners at the Women's Class II-A Prison Jakarta is $56.5 \%$. There is a significant relationship between age and recidivism status with the level of depression in prisoners at the Women's Class II-A Prison Jakarta.

This study recommends the Women's Class II-A Prison Jakarta to increase attention to mental health by conducting regular screening for prisoners to monitor and periodically monitor the mental health conditions of prisoners. Also, institutions are expected to be able to carry out preventive and rehabilitative efforts through psychological rehabilitation programs for prisoners such as stress management, counseling and other interventions as well as improving supervision related to guidance followed by prisoners.

\section{References}

Action Mental Health. (2019). Depression in young people. UK: Action Mental Health. Retrieved February, $2^{\text {th }} 2019$, from https://www.amh. org.uk/news/depression-in-young-people/

Bhuyan, N., \& Das, T. (2012). Prevalence of depression among under trial prisoners (UTPS) of Odisha. Indian J Health Wellbeing, 3(20), 750-753.

Datta, P., M, V., IV, K., BS, B., MT, S., \& S, R. (2015). Prevalence Of Depression And Assessment Of Its Severity Among Prisoners Of Central Prison, Rajahmundry, India. Indo Am J Pharma Res, 5(9), 2893-2898. 
Gulo, K. J. (2015). Hubungan Antara Dukungan Sosial Keluarga Dengan Depresi Pada Narapidana Di LAPAS II A Wirogunan Yogyakarta. Thesis. Yogyakarta: Universitas Gadjah Mada.

Gunenthira Rao, R. A. (2018). A Review on Determinants of Depression among Adult Prisoner. Malaysian Journal of Medicine and Health Sciences, 75-87.

Ministry Of Health. (2019). Basic Health Survey in 2018. Jakarta: Ministry Of Health

Nora, A. N. (2011). Komunikasi ibu dan anak dengan depresi pada remaja. Humanitas, $8(1), 45-61$.

Seewald, S. F. (2012). Severe mental illness in 33588 prisoners worldwide: Systematic review and meta-regression analysis. British Journal of Psychiatry, 200, 364-373.

Shrestha, G., Yadav, D. K., Sapkota, N., Baral, D., Yadav, B. K., Chakravartty, A., \& Pokharel, P. K. (2017). Depression among inmates in a regional prison of eastern Nepal: a crosssectional study. BMC Psychiatry, 17(348).
T.K Beyen, A. d. (2017). More than eight in every nineteen inmates were living with depression at prisons of Northwest Ambara Regional State, Ethiopia, a cross sectional study design. BMC Psychiatry, 17, 1-9.

Utami, R. d. (2011). Tingkat Depresi pada Narapidana Wanita: Studi Deskriptif pada Narapidana Lapas Kelas II A Semarang. Jurnal Psikologi, 1(4), 40-47.

World Health Organization. (2008). Trencin Statement On Prisons And Mental Health. USA: World Health Organization. Retrieved February, $8^{\text {th }} 2019$, from http://www.euro. who.int/_data/assets/pdf_file/0006/99006/ E91402.pdf

World Health Organization. (2018). Depression. . USA: World Health Organization. Retrieved February, $8^{\text {th }} 2019$, from https://www.who. $\mathrm{int} /$ news-room/fact-sheets/detail/depression

Zakir Abdu, T. K. (2018). Prevalence and Associated Factors of Depression among Prisoners in Jimma Town Prison, South West Ethiopia. Hindawi Psychiatry Journal. Vol 2018 (1-10) 